\title{
O PODER LEGISLATIVO E AS POLÍTICAS EDUCACIONAIS: A ÓTICA CIDADÃ SOBRE O CONTEXTO RECENTE
}

\section{THE LEGISLATURE AND EDUCATION POLICIES: A CITIZEN PERSPECTIVE ON THE BRAZILIAN RECENT CONTEXT}

\author{
Antonio Teixeira Barros \\ Lúcio Meireles Martins*
}

Resumo: Estuda as percepções de cidadãos sobre políticas educacionais e a atuação do Poder Legislativo no contexto recente. A metodologia consiste na técnica de survey, com aplicação de questionário com amostragem nacional de 1.010 informantes, além de pesquisa bibliográfica e documental. O papel do Poder Legislativo é associado pelos cidadãos consultados diretamente à garantia de recursos orçamentários e à fiscalização financeira relativa à aplicação dos investimentos públicos no setor. As preocupações prioritárias dos cidadãos manifestam-se de forma ambígua: ora com o nível elementar/instrumental do ensino, ora com a formação cultural, moral e ética, de acordo com a pergunta.

Palavras-chaves: Educação e Política; Políticas Educacionais; Poder Legislativo e Educação; Câmara dos Deputados e Educação.

Abstract: This article examines the perceptions of citizens on educational policies and the actions of Legislature in recent context. The methodology consists in the art of survey with a questionnaire for national sample of 1,010 respondents, as well as literature and documents. The role of the legislature is associated consulted directly by citizens to ensuring budgetary resources and financial oversight on the implementation of public investment in the sector. The priority concerns of citizens manifest themselves in an ambiguous way: on one side is with the elementary level / instrumental teaching, on the other hand is with the cultural, moral and ethical, according to the question.

\footnotetext{
*Antonio Teixeira Barros, Pós-doutor em Jornalismo Ambiental pela Universidade Fernando Pessoa (Portugal), Doutor em Sociologia pela Universidade de Brasília, Mestre em Comunicação pela Universidade de Brasília. É Professor e Orientador do Programa de Pós-Graduação do Cefor e Analista Legislativo/Comunicação Social da Câmara dos Deputados. (antonibarros@gmail.com)

Lúcio Meireles Martins, Especialista em Instituições e Processos Políticos do Legislativo, Graduado em Comunicação Social com habilitação em Relações Públicas. É Analista Legislativo/Comunicação Social na Câmara dos Deputados, integrante do grupo de pesquisa do CEFOR "Interatividade, visibilidade e transparência: estratégias da Câmara dos Deputados para aperfeiçoamento da democracia”. (luciogoiano@ hotmail.com)
} 
Keywords: Education and Politics; Educational Policies; Legislature and Education; Brazil.

\section{Introdução}

Na perspectiva do modelo republicano de democracia, a formação da opinião e da vontade coletiva é um dos aspectos fundamentais, conforme argumenta Habermas (1997). As instituições legislativas exercem papel reconhecidamente relevante, do ponto de vista da concepção deliberativa da democracia. Nessa perspectiva, as cortes parlamentares deveriam atuar como radares para captar a opinião pública, além de caixas de ressonância para a percepção e a vontade do cidadão, manifestas nas esferas públicas informais. Dessa forma, a opinião do cidadão é que constitui a força motriz dos regimes democráticos, a essência da soberania popular. Afinal, a política se baseia na capacidade de formar opinião. Enquanto as ciências exatas e naturais operam com evidências racionais ou provas empíricas expressas em definições, postulados, teoremas e similares (discursos monológicos), a política situa-se no campo dialógico da pluralidade de ideias e opiniões, uma vez que se trata de uma atividade que se instaura na relação entre os homens, ou seja, a pluralidade está na sua própria origem, como explica Arendt (1983).

Sob esse ângulo analítico, a educação exerce papel fundamental para a formação de cidadãos com ampla cultura cívica e reconhecidas habilidades para participar do debate público, um dos elementos inerentes à noção de esfera pública, segundo a visão habermasiana. O autor destaca o papel da cultura cívica nas relações discursivas na esfera pública, entendida aqui como o domínio social da argumentação coletiva, com reflexos nas visões que a sociedade formula sobre os fenômenos sociais, a exemplo da educação, um dos serviços públicos essenciais no atual contexto. É pela troca pública de argumentos e opiniões, conforme Habermas (1997), que os cidadãos conseguem contribuir para o esclarecimento das questões fundamentais para a vida coletiva. $\mathrm{O}$ parlamento é visto, nesse contexto, como instância de regulação da vida pública, capaz de acomodar a diversidade dos homens e dos seus interesses sob a unidade das normas juridicamente instituídas (HABERMAS, 1997).

É com base nesses pressupostos mais amplos que este artigo tem como objetivo analisar as percepções do público sobre a atuação do parlamento, com foco específico nas políticas educacionais e seus efeitos, a partir das seguintes questões: (a) que áreas da educação necessitam de mais atenção do Poder Legislativo? (b) como o Poder Legislativo pode contribuir para aperfeiçoar o ensino público? (c) o que deve ser prioritário para aperfeiçoar o ensino público? (d) quais os avanços mais relevantes nas últimas décadas?

Os dados expressam a opinião da população das cinco regiões geográficas brasileiras e apresentam, em linhas gerais, as tendências mais expressivas da opinião dos cidadãos ouvidos durante a sondagem. A coleta de dados foi realizada por telefone, por uma equipe do Disque- 
Câmara ${ }^{1}$, por meio de questionário estruturado, com perguntas fechadas, em março de 2012. No total foram ouvidas 1.010 pessoas. Os parâmetros quantitativos da amostra foram definidos de acordo com a distribuição populacional nas cinco regiões, conforme dados do último censo do Instituto Brasileiro de Geografia e Estatística (IBGE), de modo a contemplar uma amostragem equilibrada da população, segundo o perfil demográfico regional. A sondagem de opinião foi conduzida pela Secretaria de Comunicação da Câmara dos Deputados, no segundo semestre do ano de 2011, com o objetivo de avaliar as percepções da sociedade sobre a atuação do Poder Legislativo na área de políticas educacionais. Busca-se ainda comparar os dados com pesquisas que avaliam a educação pública por meio de estudos de opinião pública. Apesar destes levantamentos não terem foco na atuação do Poder Legislativo nessa área, apresentam temáticas correlatas ao levantamento enfocado.

O enquadramento teórico foi construído a partir do contexto analítico mais amplo que sustenta o pensamento social e político no que se refere aos estudos sobre a relação entre política, educação e esfera pública. Assim, optamos, em primeiro plano, pela perspectiva da sociologia weberiana, que associa educação ao âmbito do desenvolvimento da racionalização das sociedades ocidentais e à formação de uma opinião pública laica, ou seja, desvinculada do universo religioso. De forma complementar, adotamos as convergências do pensamento weberiano com as ideias de Hannah Arendt e Habermas. Destaca-se nessa convergência a análise social em que educação e política são vistas como fundamentos da esfera pública moderna, com sua pluralidade de percepções e opiniões, com seus impactos no mundo da vida e no campo experiencial do cotidiano.

Antes, contudo, é necessário ressaltar que o escopo da relação entre os temas pertinentes ao campo educacional e a esfera de competência do Poder Legislativo é amplo, ambíguo e complexo, o que significa um assunto difícil de ser caracterizado no curto espaço de um artigo. Por esse motivo, destacaremos alguns dos aspectos mais relevantes, embora sucintamente, iniciando pela abordagem institucional desenhada nas últimas décadas.

No Brasil, até o final da década de 1980, a relação entre educação e o Poder Legislativo se limitava à organização do sistema escolar por meio da legislação (COSSON, 2008; MARQUES JÚNIOR, 2009), com um fórum parlamentar específico, ou seja, a comissão temática responsável pelo assunto, com uma agenda de longos anos de discussão (nem sempre continuada). No caso da Lei de Diretrizes e Bases da Educação Nacional de 1961 (Lei Federal 4.024/61), foram 13 anos de debate, por exemplo, o que pode levar a população a achar que o assunto que não recebe a devida atenção dos parlamentares.

Entretanto, devido a uma tendência internacional de valorização da educação para a democracia e a cidadania (COSSON, 2008) e também como provável tentativa dos parlamentos de

\footnotetext{
${ }^{1}$ Os atendentes foram treinados e supervisionados por uma equipe de pesquisadores, com suporte técnico e estatístico de funcionários da empresa terceirizada responsável pela operação do Disque-Câmara (0800619619).
} 
responderem à crise generalizada de falta de confiança da sociedade (RIBEIRO, 2011), a educação passou a ser tratada de forma diferenciada nos últimos anos pelo Congresso Nacional brasileiro. Isso resultou em várias iniciativas avaliadas como relevantes e positivas, tais como a definição de mecanismos de financiamento e de avaliação da educação pública, o que representa um marco na consolidação do tema como política pública, com a participação do Poder Legislativo como protagonista (MARTINS, 2011). ${ }^{2}$

\section{Educação como legado racional e ético}

A educação no sentido social e político mais abrangente encontra respaldo na análise weberiana sobre o processo de racionalização cultural do Ocidente (WEBER, 1999). Em outras palavras, na abordagem weberiana, educação e política são vistas como resultantes do projeto amplo de racionalização das sociedades ocidentais, contribuindo ambas para a secularização e o "desencantamento" do mundo social ${ }^{3}$. Weber ressalta o potencial civilizador da racionalização, seja na economia, na ciência, na educação, na cultura, na política e na legislação. Em sua dimensão intelectual, diretamente associada à educação, a racionalização é vista por Weber como indutora do processo civilizatório. Foi a racionalização que possibilitou uma cultura baseada na liberdade de expressão e de opinião.

Esse processo permitiu que a educação se tornasse protagonista de narrativas sociais desvinculadas do pensamento mágico e religioso, o que nos levou à elaboração de uma leitura do mundo renovada e ancorada em bases racionais e legais. Cabe reforçar que o próprio conceito de progresso, intrinsecamente associado à modernidade, decorre da noção de desencantamento do mundo e sua consequente secularização e normatização legal e racional. Essa visão de educação está diretamente relacionada à ideia weberiana de 'dominação legal', ou seja, formas de poder baseadas em estruturas e leis racionais e impessoais, orientadas para o bem coletivo, pela ética da responsabilidade, e não mais pela ética da convicção, típica do âmbito religioso. ${ }^{4}$

Nessa trajetória, a educação é considerada politicamente emblemática no engendramento da relação política do cidadão com o Estado, com as instituições, com os seus concidadãos. Afinal, uma das funções políticas da educação é incentivar o zelo pela res publica,

\footnotetext{
${ }^{2}$ No âmbito do financiamento público, o autor destaca o Fundo de Manutenção e Desenvolvimento da Educação Básica e de Valorização dos Profissionais da Educação (Fundeb), que atende toda a educação básica, da creche ao ensino médio. Substituto do Fundo de Manutenção e Desenvolvimento do Ensino Fundamental e de Valorização do Magistério (Fundef), que vigorou de 1997 a 2006, o Fundeb está em vigor desde janeiro de 2007 e se estenderá até 2020. Já no campo da avaliação, destaca-se o Exame Nacional do Ensino Médio (Enem) e o Exame Nacional de Desempenho de Estudantes (Enade), que integra o Sistema Nacional de Avaliação da Educação Superior (Sinaes).

${ }^{3} \mathrm{O}$ desencantamento do mundo ou "desmagificação", na perspectiva weberiana, implica a substituição das visões mágicas e religiosas pelas explicações racionais, filosóficas e científicas.

${ }^{4}$ De forma muito resumida, a diferença é que a ética da responsabilidade, como expressão racional, considera o cálculo estratégico das ações e leva o seu agente a arcar legalmente com as consequências de seus atos, enquanto a ética da convicção é baseada puramente em elementos subjetivos e emocionais, como a fé religiosa e o pensamento político ideológico e dogmático.
} 
a polis e o mundo, entendidos aqui nos termos filosóficos de Hannah Arendt (1983), ou seja, como a esfera do comum, resumida na noção de espaço público, cuja função é iluminar o âmbito da ação política. É na esfera pública que os fatos, as opiniões, os argumentos e as pessoas emergem da obscuridade do âmbito privado e adquirem visibilidade pública.

Para Hannah Arendt (1999), a progressiva perda de sentido da política e o avanço da 'banalidade do mal', fenômenos acentuados com as experiências totalitárias que marcaram o pós-guerra, estão diretamente relacionados com o que ela denominou de "crise na cultura". Tal crise é caracterizada como a redefinição do papel das instituições culturais, que são essenciais para a formação de habilidades essenciais ao exercício da política, tais como o pensar, o querer e o julgar. Assim, em vez de preparar cada nova geração para assumir seu lugar na esfera pública, as instâncias culturais e simbólicas da sociedade moderna, regidas pela lógica do pragmatismo pedagógico, colocaram a capacidade formadora de cidadãos, no sentido pleno, em segundo plano. Isso se refletiu diretamente na formação de mentalidades e de habilidades voltadas para a ação política dialógica, o debate de ideias, a consciência coletiva, a pluralidade do pensar.

Ao desenvolver seu raciocínio, Arendt produz pensamento político combinado com hermenêutica da cultura, a partir da uma reflexão filosófica e sociológica sobre como acomodar o novo no mundo. Afinal, a criança é nova no mundo e o mundo é novo para a criança. Assim, a escola é um lugar de novidade para a criança e um espaço de produção de inovação. Contudo, se a inovação e a reinvenção do mundo são essenciais, a conservação também o é. Desse modo, a autora defende uma relação dialética entre o novo e o tradicional, ao lembrar que não existe futuro sem passado, que não há inovação sem tradição. Em outras palavras, o florescer de inovações requer raízes de tradição para nutrir e alimentar os brotos e rebentos entregues ao mundo pela natalidade (ARENDT, 2000). A Educação é o agente mediador entre o velho e o novo, entre a criança e o mundo. É a educação que prepara o cidadão para atuar na esfera pública, por meio de um contrato dialógico entre os velhos e os novos. Trata-se, pois, de um compromisso hermenêutico entre o horizonte de compreensão ligado ao passado, ancorado no presente, mas com vistas ao futuro. Isso implica uma compreensão da política do ponto de vista racional e ético, como já foi ressaltado.

Uma contribuição teórica expressiva para o aprofundamento dessa discussão está na obra de Habermas (1987), sobre o poder hermenêutico da construção, interpretação e compartilhamento de sentidos na esfera pública. A visão hermenêutica de Habermas tem relação direta com o pensamento de Weber e Arendt, uma vez que se situa no âmbito dos desdobramentos dos estudos sobre racionalidade cultural.

Para Habermas, a educação serve de substrato para a esfera pública e contribui para integrar três elementos estruturais: a cultura, a sociedade e a personalidade. O primeiro é entendido por Habermas como o acervo de saberes acumulado historicamente, em que os 
participantes da comunicação se abastecem de interpretações para entender algo do mundo. $\mathrm{O}$ segundo é concebido como um sistema composto por ordenações legítimas, mediante as quais os participantes de uma rede social regulam sua forma de participação e pertencimento a grupos sociais e instituições. Já o terceiro, caracterizado pela personalidade, é traduzido pela competência nos processos que possibilitam a um sujeito ter linguagem e ação, que o habilitam a fazer parte de processos de entendimento e compartilhamento de sentidos, além de afirmar neles sua própria identidade (HABERMAS, 1987). Trata-se, pois, da esfera que contribui para manter a identidade social e cultural dos indivíduos e das comunidades, ao favorecer o compartilhamento de valores, a livre expressão de ideias, a comunicação de natureza mais participativa e menos instrumental. Afinal, a esfera pública é apontada pelo autor como um domínio social de argumentação coletiva (HABERMAS, 1997).

A perspectiva de Habermas apresentada em 'Mudança estrutural da esfera pública' e posteriormente em 'Direito e democracia' é complementar à reflexão de Weber e de Hannah Arendt. Para Habermas o desenvolvimento histórico da noção de esfera pública é produto da educação secular, ou seja, decorrente de uma "revolução moral e política resultante do processo de formação e autonomização da subjetividade burguesa no século XVIII", desvinculada da visão de mundo até então moldada pela religião (SOUSA, 2000, p.61). O processo de aprendizado político na esfera pública é que permite ao cidadão desenvolver suas competências em termos de argumentação e uso público da razão, a fim de construir discursivamente o consenso social. Afinal, "as necessidades não exprimíveis em linguagem não têm lugar na esfera pública" (SOUSA, 2000, p.77), o que nos leva a deduzir que a competência comunicativa é fundamental e a escola é um dos espaços privilegiados para o desenvolvimento de tal habilidade.

Na leitura de Weber e Habermas, percebe-se em comum o reconhecimento de que a educação "faz parte do processo de racionalização moral que permite o desabrochar do direito burguês da igualdade (sobretudo civil, mas em parte também política) e uma mentalidade universalista perante os indivíduos" (DOMINGUES, 2000, p.216). E isso só foi possível devido à construção histórica do conceito de indivíduo, capaz de pensar por si e atuar na sociedade. Afinal, "o indivíduo não é um dado, mas surge progressivamente na história", favorecido, inclusive pela educação, além do desenvolvimento da cultura urbana. Desse processo originouse a liberdade de consciência, que mais tarde embasaria as ideias sobre liberdade de participação (DOMINGUES, 2000, p.213).

\section{Análise dos Dados}

Tendo em perspectiva o amplo horizonte teórico acima delineado, a parte empírica do artigo analisa a relação entre educação, legislação e opinião pública no contexto brasileiro, em razão dos pressupostos enunciados anteriormente. Nessa perspectiva, a educação exerce papel 
fundamental para a formação de cidadãos com ampla cultura cívica e reconhecidas habilidades para participar do debate público, um dos elementos inerentes à noção de esfera pública, segundo a visão habermasiana, conforme foi abordado na primeira parte do texto.

\subsection{Perfil dos respondentes}

A descrição e análise dos dados é iniciada com o perfil dos cidadãos que responderam ao questionário (Gráficos de 1 a 3), com base nas seguintes variáveis: escolaridade, faixa etária, gênero, região geográfica e ocupação / profissão. Na sequência apresentam-se os dados, de acordo com a ordem das perguntas. Como se trata de uma sondagem sobre educação, supõe-se que a variável escolaridade seja relevante para a análise e compreensão dos resultados. Por essa razão, optou-se pela apresentação dos dados gerais em comparação com as respostas vinculadas ao grau de instrução dos respondentes, a fim de avaliar se existem diferenças e/ou semelhanças entre os três níveis do perfil dos respondentes. ${ }^{5}$ Prevalecem os percentuais referentes à escolarização superior $(45,35 \%)$, gênero masculino $(62,38 \%)$, na faixa etária acima de 50 anos $(45,45 \%)$.

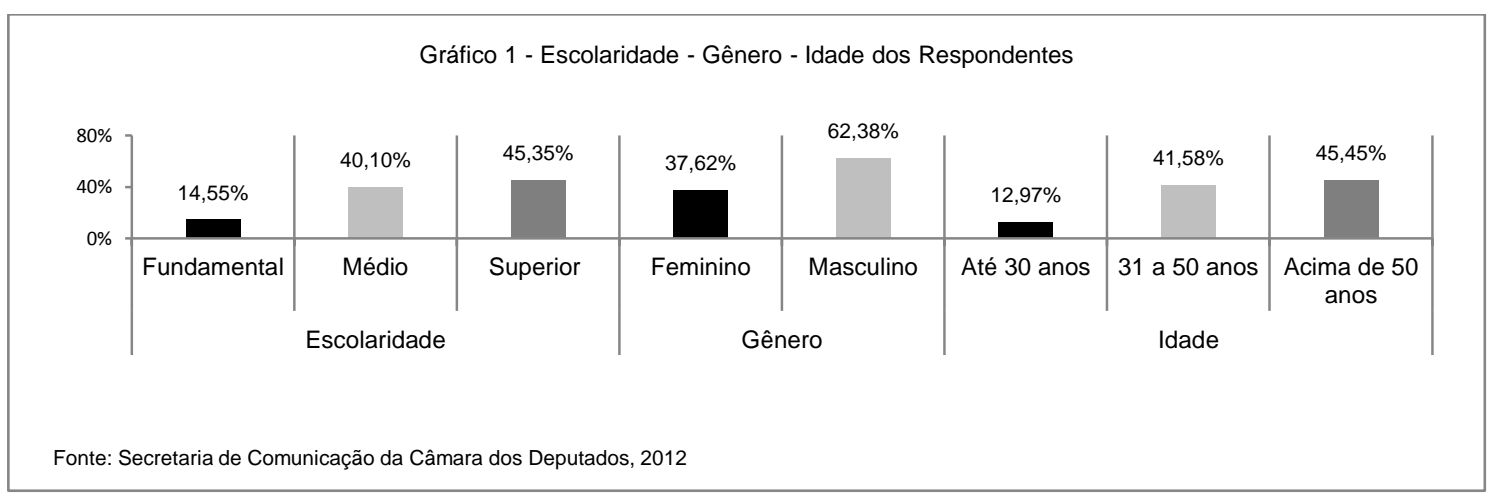

Quanto à região dos respondentes, prevalecem as regiões Nordeste $(32,08 \%)$ e Sudeste $(29,70 \%)$, com menor expressividade da região Norte (6,34\%), como se vê no Gráfico 2.

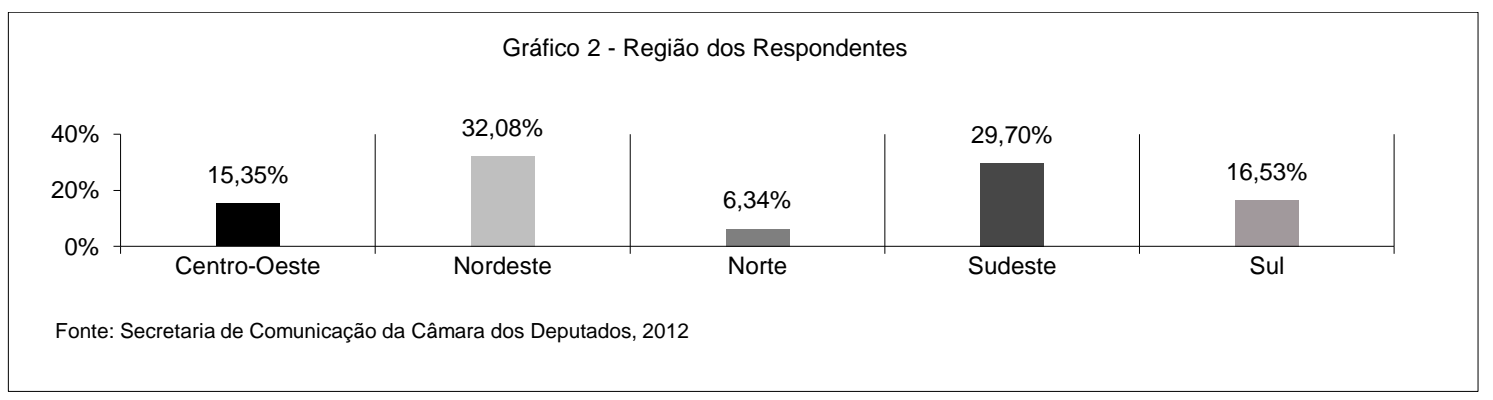

$\mathrm{Na}$ área profissional, destacam-se autônomos, servidores públicos e profissionais de campos afins à educação, como mostra o Gráfico 3. O predomínio de "outros" se justifica pela amplitude do cadastro nacional de ocupações. Cabe mencionar o próprio sistema de classificação

\footnotetext{
${ }^{5}$ Os dados brutos da pesquisa consideravam também os cenários regionais de opinião, ou seja, as respostas da mesma pergunta foram tabuladas conforme cada região geográfica. Contudo, o que se observou foi que, apesar das reconhecidas e difundidas diferenças culturais, não há cenários de opinião pública específicos e distintos quando se trata de educação, pelo menos conforme o enquadramento da sondagem. Predominam as convergências e consonâncias em relação ao contexto nacional.
} 
das profissões usado ${ }^{6}$, uma vez que a categoria "outros" atinge 64,95\%, ou seja, quase dois terços. O predomínio de "outros" passa a ser um dado relevante na medida em que é indicado como a maioria dos entrevistados, portanto. Resulta do somatório de profissões fragmentadas e dispersas, tendo em vista que o cadastro nacional de ocupações registra 7.258 títulos ocupacionais. A amplitude desse universo dificulta a citação nominal de categorias profissionais que representam esse percentual.

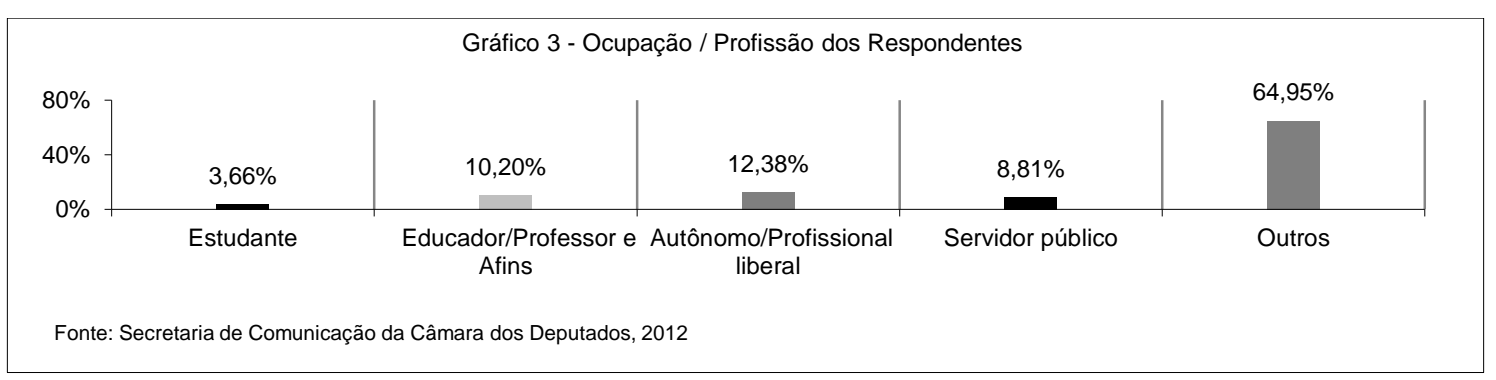

\subsection{Que áreas da Educação que precisam de mais atenção do Poder Legislativo?}

Ao se considerar o total geral de respostas, percebe-se que todas as áreas mencionadas no questionário são apontadas como relevantes pelos cidadãos consultados, com percentuais similares, que variam de $16,69 \%$ a 26,13\%, como mostra o Gráfico 4. Nessa escala, ficaram com os maiores percentuais a educação básica $(26,13 \%)$ e a o ensino técnico profissionalizante $(20,63 \%)$. O ensino superior e a pós-graduação registram o menor índice de respostas, com 16,69\%.

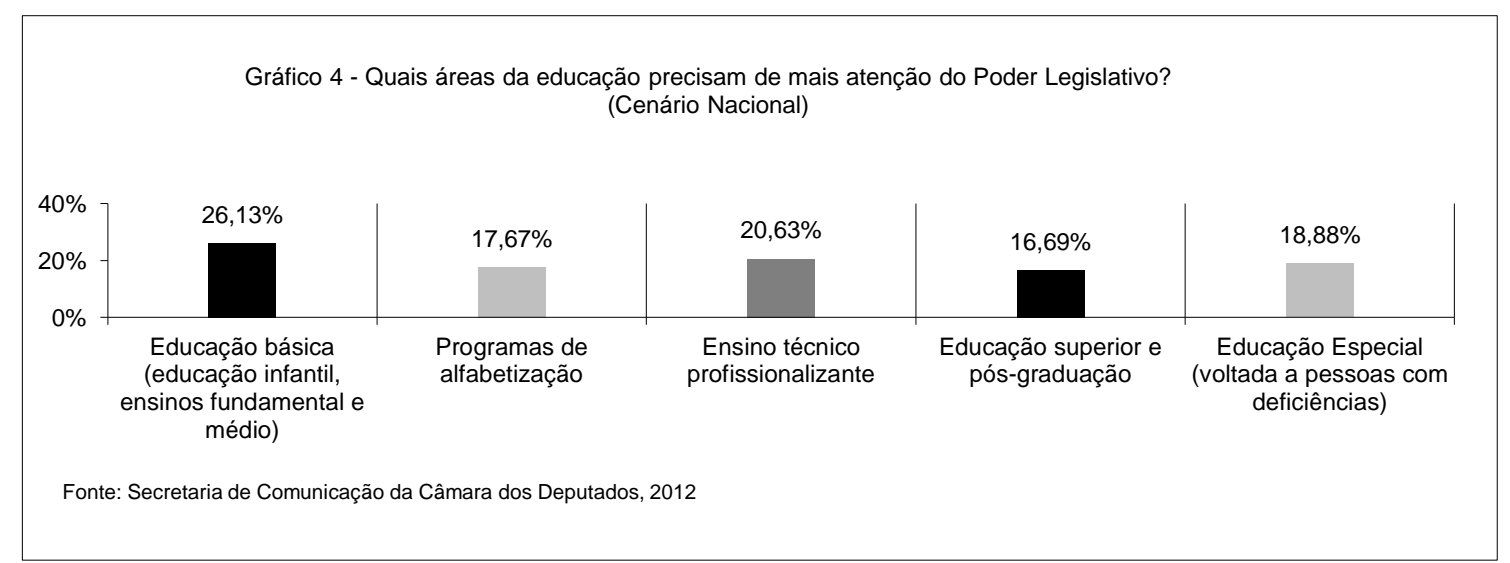

Pesquisa de opinião pública do Senado Federal $^{7}$ (BRASIL, 2011) demonstrou que $85 \%$ da população é a favor de que as creches sejam consideradas como a primeira fase da educação. Nesse mesmo contexto, para $63 \%$ o ensino fundamental é aquele que deve receber maior aplicação de recursos públicos, sendo que o ensino médio foi apontado por $24 \%$ e o ensino superior $10 \%$. A

\footnotetext{
${ }^{6}$ O sistema é baseado na Classificação Brasileira de Ocupações (CBO), instituída pela Portaria Ministerial no ${ }^{\circ} .397$, 2002. A CBO contempla 7.258 títulos ocupacionais. A finalidade é a identificação das ocupações no mercado de trabalho para fins de registros administrativos. Mais informações em http://www.mtecbo.gov.br/cbosite/pages/saibaMais.jsf

${ }^{7}$ Dados coletados de 24 e junho a 7 de julho de 2011, totalizando 1343 entrevistas realizados pela Secretaria de Pesquisa de Opinião Pública/DataSenado.
} 
mesma questão em pesquisa de opinião pública do Senado Federal de setembro de 2013 reforça essa necessidade de maior financiamento ao ensino fundamental, com 65,2\% das respostas, $21,9 \%$ para o ensino médio e apenas 11,2\% para o ensino superior (BRASIL, 2013).

Apesar da diferença nas alternativas apresentadas aos pesquisados, evidencia-se o mesmo foco de preocupação da população quanto à educação pública, no período anterior à vida adulta. Esses dados são corroborados pela demanda não atendida da educação infantil, já que o Anuário Brasileiro da Educação Básica (2014) ${ }^{8}$ mostra que, em 2012, apenas 23,5\% das crianças de 0 a 3 anos estavam em creches, sendo que, no quartil (25\%) mais rico da população, eram 44\%, enquanto as famílias mais pobres tinham apenas $16,2 \%$ de suas crianças matriculadas. Na faixa etária de 4 e 5 anos, os números apresentam uma melhor situação, apesar da manutenção da desigualdade por renda. No mesmo ano registrou-se $82,2 \%$ de crianças matriculadas, sendo $94,6 \%$ no quartil dos mais ricos e apenas $77,6 \%$ entre os $25 \%$ mais pobres. O Plano Nacional de Educação (2014-2020), sancionado por meio da Lei n 13.005/2014, estabeleceu como meta que, até 2016, $100 \%$ das crianças de 4 e 5 anos estejam na escola e que, em até 10 anos, $50 \%$ das crianças de 0 a 3 anos estejam na educação infantil. Isso demandará não só que os gestores e governantes priorizem a educação pública, mas também que a sociedade acompanhe e controle a execução dessa determinação legal.

Em consonância com o cenário geral, todas as áreas mencionadas no questionário são apontadas como relevantes pelos cidadãos consultados, independentemente do grau de escolaridade, como mostra o Gráfico 5. A variável escolaridade não constitui, portanto, um fator preponderante para avaliar as áreas da educação pública que deveriam receber maior atenção do Poder Legislativo. Uma avaliação dessa questão com maior profundidade necessitaria de um estudo com outros parâmetros estatísticos, como nível de renda, profissão, faixa etária, entre outros.

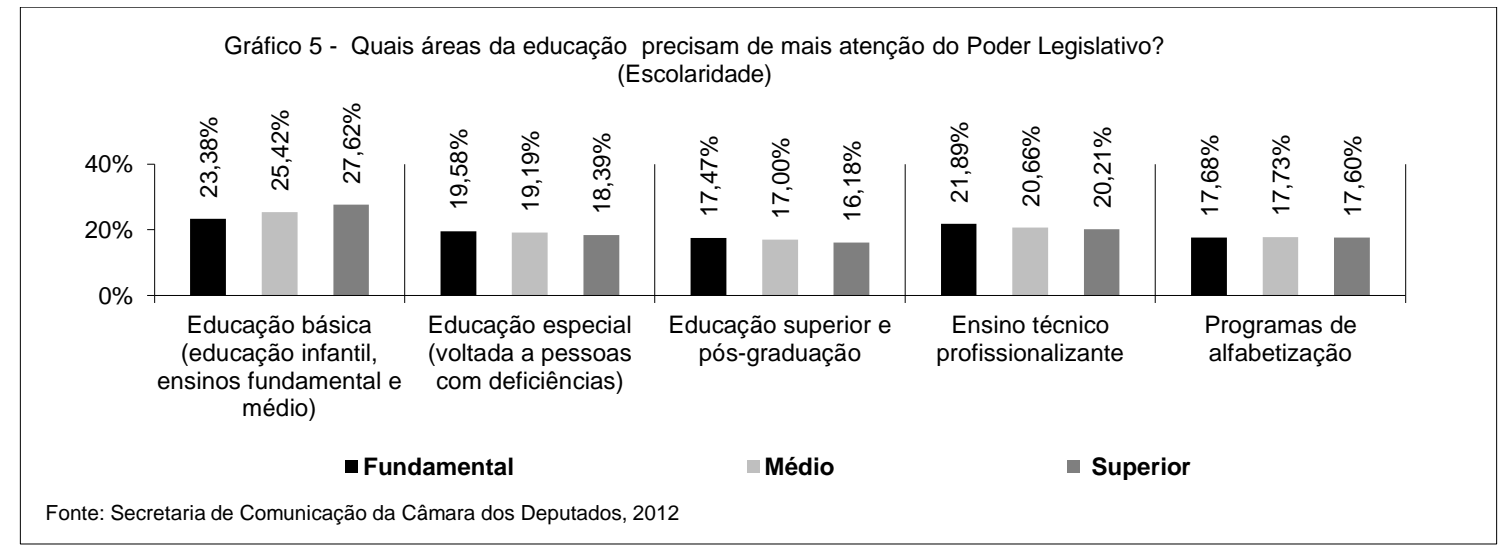

\footnotetext{
${ }^{8}$ Dados elaborados pela Todos pela Educação com base em números do IBGE/Pnad.
} 


\subsection{Como o Poder Legislativo pode contribuir para melhorar o ensino público?}

Como se trata de uma pesquisa de opinião focada na relação entre legislação e educação, o questionário apresentava um item sobre a opinião da população sobre atuação do Poder Legislativo no sentido de aperfeiçoar o ensino público. Os dois itens associados à gestão e fiscalização dos recursos públicos destinados à educação são apontados como os mais relevantes quando se trata do papel do Poder Legislativo em relação à instrução pública. Como mostra o Gráfico 6, fiscalizar a aplicação dos recursos $(28,88 \%)$ e assegurar mais recursos orçamentários $(25,40 \%)$ são os itens principais, o que soma 54,28\%. Em seguida, destacam-se as seguintes ações legislativas: aprovação de medidas para promover a capacitação dos professores $(25,70 \%)$ e a promoção de debates sobre temas educacionais $(20,02 \%)$. Portanto, o Poder Legislativo é visto pelos cidadãos consultados mais como um órgão capaz de interferir na gestão da educação, em detrimento da função de discutir e promover debates.

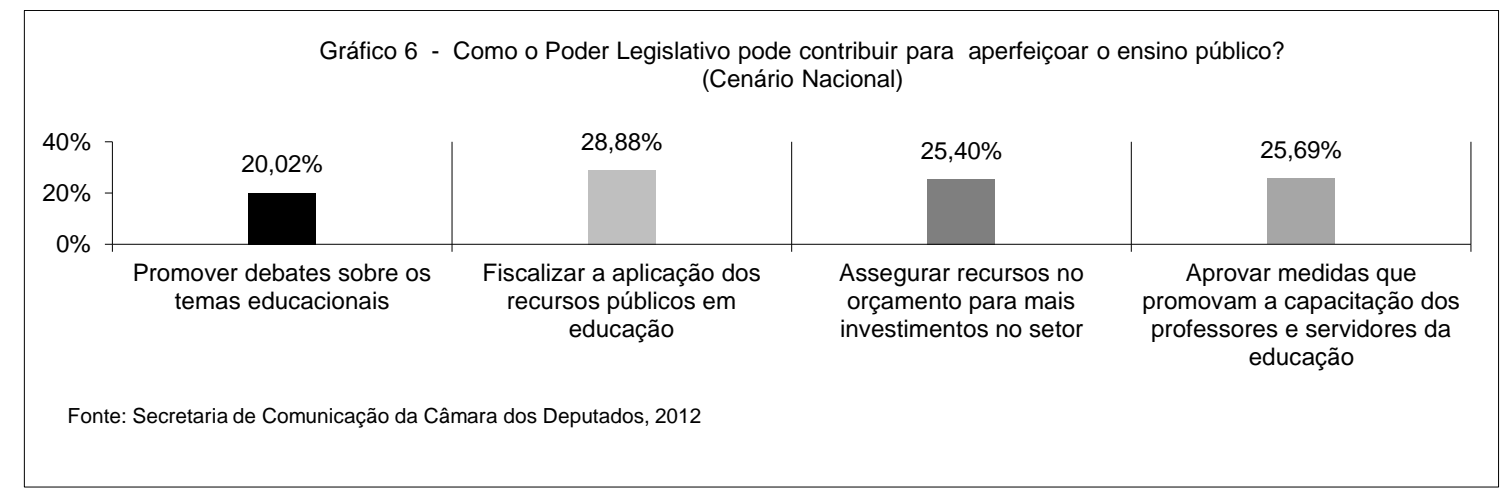

O diferencial nesse quesito, no que se refere especificamente aos dados segmentados por escolaridade dos respondentes, diz respeito ao percentual um pouco mais elevado de cidadãos com ensino médio que reconhecem a função de promover debates sobre temas educacionais como uma contribuição relevante do Poder Legislativo para a melhoria da qualidade do ensino público, como mostra o Gráfico 7. No primeiro caso, portanto, o Poder Legislativo é percebido mais como uma instância política de ação instrumental, ou seja, de viabilizar a gestão educacional e de fiscalizar a aplicação dos recursos orçamentários destinados ao setor. Para os menos escolarizados, então, o Poder legislativo teria a função de uma agência burocrática para garantir a eficiência na área educacional, o que praticamente o confunde com o Ministério da Educação, pelo menos no que se refere ao caráter gerencial. No segundo caso, observa-se que os respondentes com maior nível de instrução reconhecem o valor da função política do Poder Legislativo como órgão que representa a pluralidade da política, como uma arena para as discussões em prol do aperfeiçoamento das políticas públicas voltadas para a educação, uma visão que se aproxima das ideias de Arendt (1983) e Habermas (1997), anteriormente discutidas. 


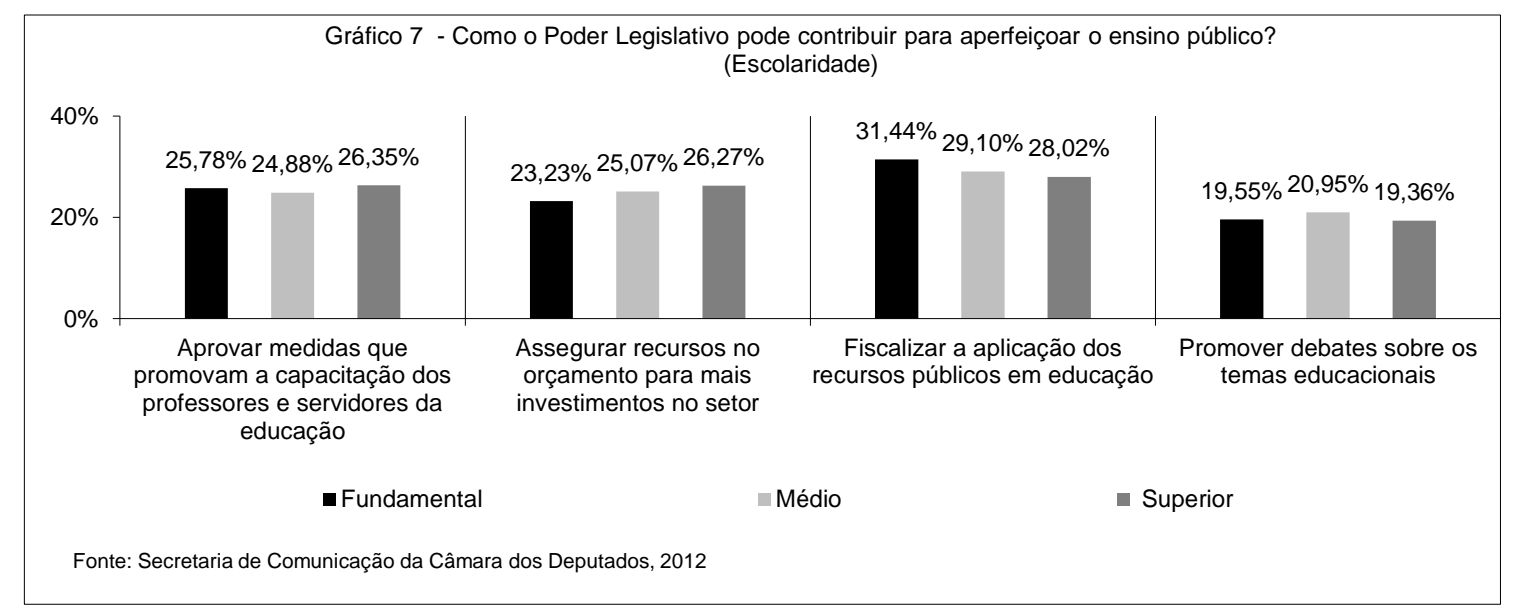

\subsection{Principal papel da Educação}

Quando perguntados sobre o principal papel da educação, a tendência geral dos respondentes segue o padrão do item anterior, ou seja, há uma dispersão das respostas, indício de que não existe um consenso nacional sobre o item objeto da pergunta. Entretanto, como mostra o Gráfico 8, prevalecem menções associadas à formação ética e moral (24,12\%), formação intelectual e cultural $(23,30 \%)$ e ao ensino voltado para o respeito às diversidades e diferenças $(20,70 \%)$. O somatório dessas três alternativas de respostas oferecidas pelo questionário resulta em 68,12\%, o que indica que o principal papel da educação, na percepção dos cidadãos, apesar da fragmentação das opiniões, é associado à formação intelectual, cultural, moral e cidadã. Os menores índices de respostas estão vinculados à dimensão instrumental e utilitarista da Educação: conduzir o estudante a um bom emprego $(17,05 \%)$ e prepará-lo para o vestibular $(14,83 \%)$.

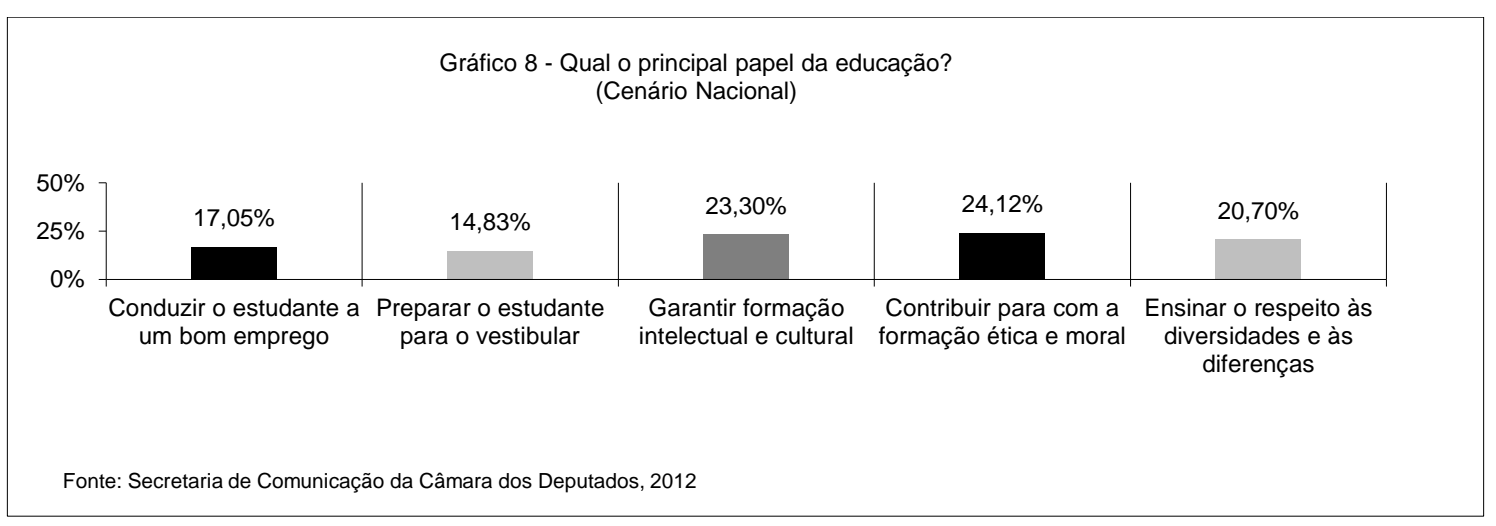

Confirmando a complexidade e um certo nível de ambiguidade nas respostas, o Gráfico 9 mostra uma dispersão nas respostas, que enfatizam tanto a formação humanística, quanto a preparação para o vestibular e o mercado de trabalho. Com uma leve vantagem estão os percentuais que ressaltam o papel formador da educação (formação ética, moral, intelectual, cultural e respeito às diferenças). Na tabulação segundo o nível de escolaridade, essa tendência se repete, confirmando 
a ambiguidade já identificada em estudo anterior (BARROS e MARTINS, 2014).

A respeito da ênfase ao papel formador, uma inferência possível é que tal percepção reflete o pensamento da população de que caberia à escola, além da instrução, a formação moral e ética, desobrigando a família da última função. Isso não significa que a escola não seja um agente de formação e socialização cidadã, entretanto a instância de socialização primária é a família, o espaço por excelência de transmissão de valores, crenças e demais elementos relacionados à esfera da reprodução social, como explicam Bourdieu e Passeron (1975), entre outros autores. Certamente, trata-se de uma concepção que resulta do próprio contexto sociocultural, em uma época de redefinição e redesenho dos modelos e funções das famílias, com cada vez menos tempo dos pais para acompanhar a formação dos filhos. Além disso, há que se considerarem as consequências decorrentes da própria "crise na educação", como denomina Arendt (2000), ao analisar o dilema das escolas entre a formação humanística em declínio e o imperativo da formação profissional, em função das demandas do mercado de trabalho.

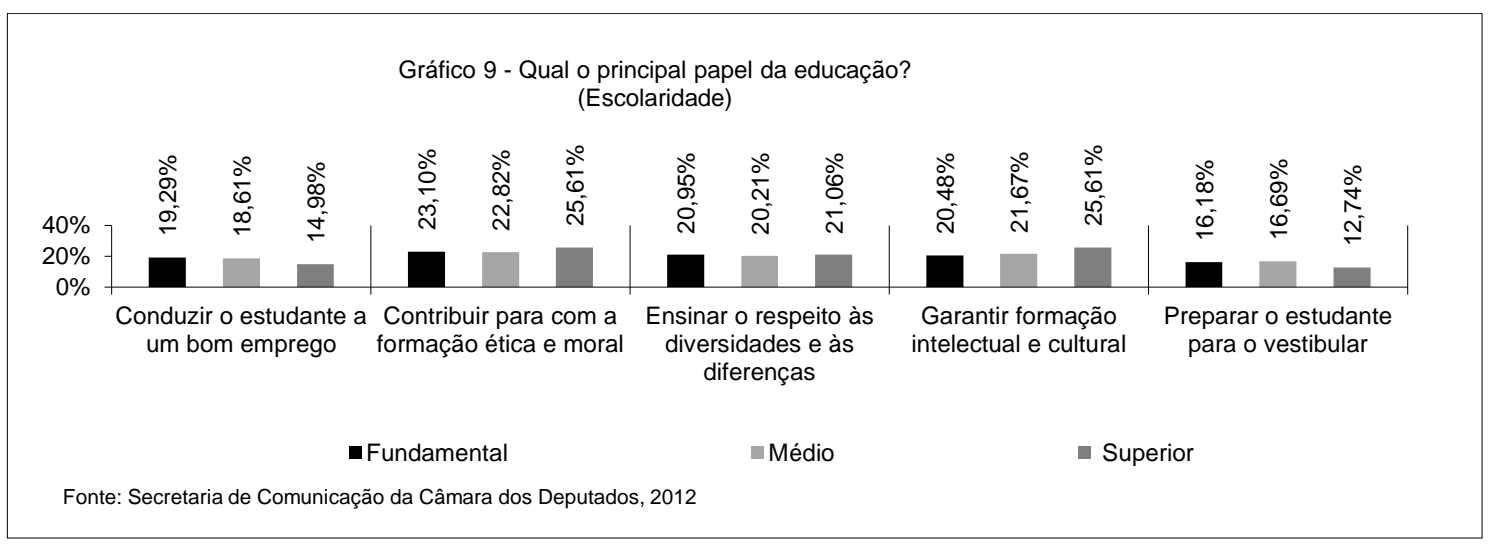

\subsection{Responsabilidade institucional pela educação}

A tendência geral das opiniões aponta para o reconhecimento de que a responsabilidade pela educação deve ser compartilhada pela União, estados e municípios, além do envolvimento da família, da comunidade, dos professores e dos próprios alunos. Nesse quesito, como mostra o Gráfico 10, cerca de 39,28\% responderam que todos são responsáveis pela educação. Os menores percentuais indicam os alunos (10,39\%) e as escolas, professores/servidores $(12,92 \%)$.

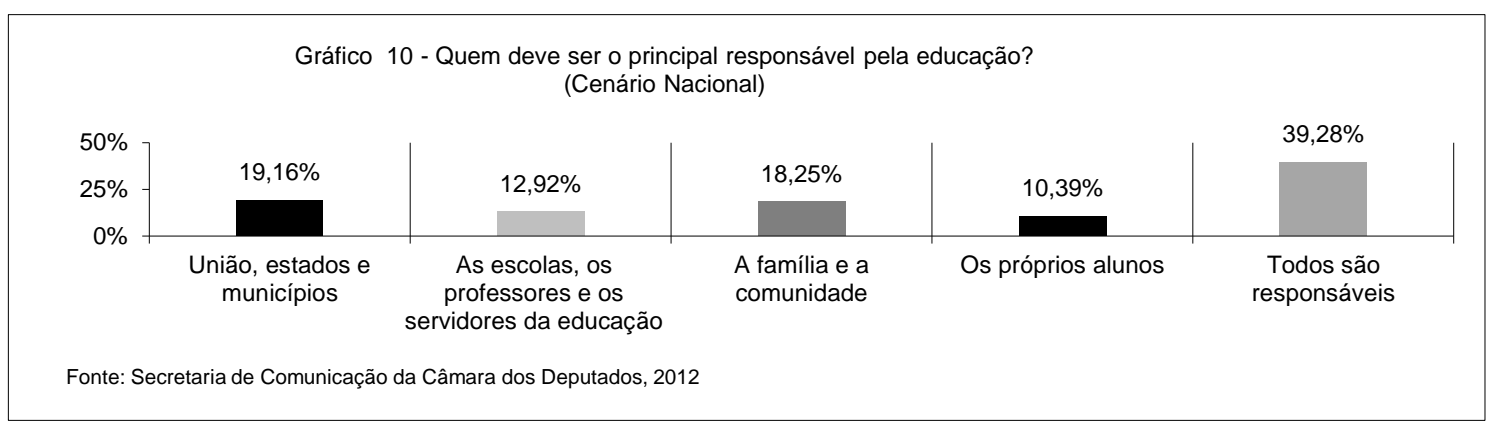


O Gráfico 11 confirma que a tendência é dominante independentemente do grau de instrução, ou seja, a maioria dos cidadãos atribui a todos a responsabilidade pela educação. A única diferença percebida é que a tabulação conforme a escolaridade mostra que tal opinião adquire mais peso à medida que se eleva o tempo de escolarização, ou seja, 32,43\% para os respondentes com o ensino fundamental; $37,15 \%$ para os cidadãos com o ensino médio; e 43,84\% para aqueles com o nível superior. A educação como responsabilidade de todos, entretanto, soa como um discurso idealizado ou uma perspectiva normativa. Reflete ainda um certo nível de engajamento retórico dos respondentes, porém descolado das práticas cotidianas. Certamente esse elevado nível de adesão à ideia de responsabilidade compartilhada é fruto da midiatização dos movimentos que defendem essa visão, a exemplo do "Todos Pela Educação" (http://www.todospelaeducacao.org.br/), fundado em 2006, que conta com o apoio de celebridades e figuras de amplo reconhecimento público, como o ex-jogador de futebol Raí. Os estudos empíricos, ao contrário, indicam um distanciamento cada vez maior entre a escola, a família e a comunidade (PAUL e BARBOSA, 2008).

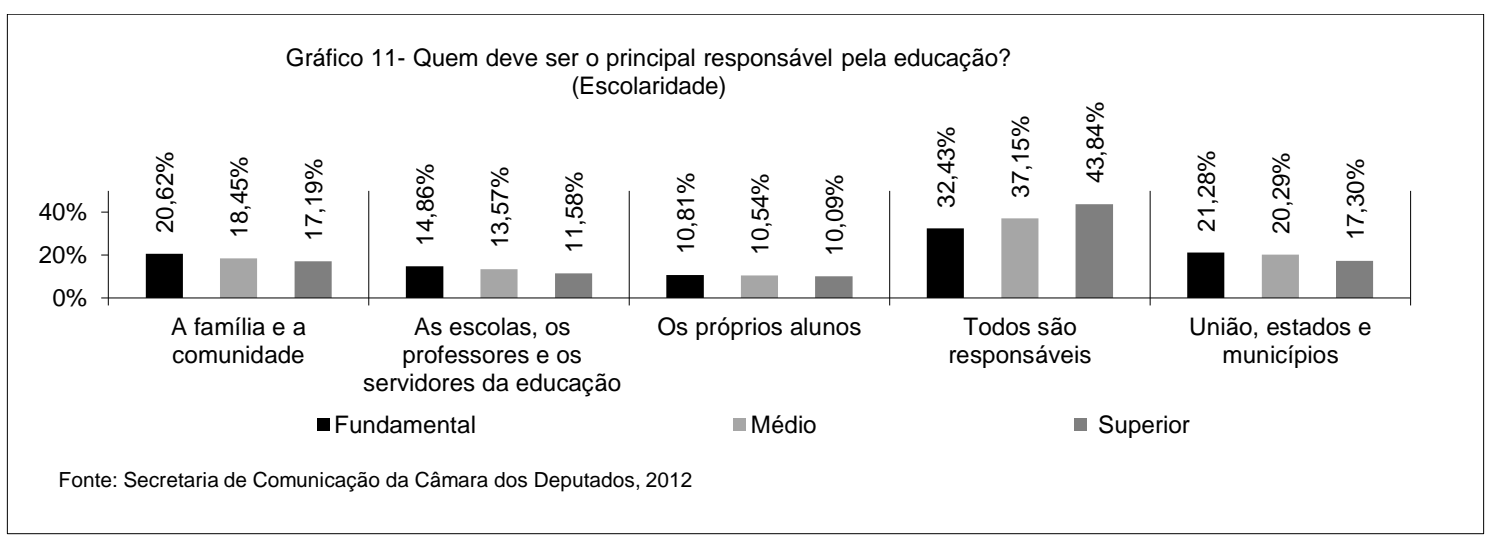

\subsection{O que é mais importante para melhorar a qualidade da Educação}

Nesse tópico, predominaram afirmativas que atribuem maior relevância aos salários e à formação continuada dos professores (24,77\%) e à infraestrutura das escolas (bibliotecas, laboratórios e computadores), com 20,71\%, como mostra o Gráfico 12. Os itens relacionados aos conteúdos dos currículos $(17,75 \%)$, gestão democrática $(18,32 \%)$ e pesquisa $(18,45 \%)$ receberam os menores percentuais. Pesquisa de opinião pública do IBOPE (2008) ${ }^{9}$ também apontou como principal problema da educação os baixos salários, tendo 19\% dos respondentes apontado essa questão, $17 \%$ a falta de segurança, $15 \%$ as 'poucas escolas' e $11 \%$ 'professores desqualificados/despreparados'. Os levantamentos do Senado Federal (BRASIL, 2011 e 2013) corroboram esses resultados, já que, ao analisarem quais seriam os maiores problemas da educação pública, $31 \%$, no primeiro estudo, e $31,7 \%$, no segundo, indicaram os baixos salários, e outros $25 \%$

\footnotetext{
${ }^{9}$ Esse estudo, realizado em 2008, contou com 2002 entrevistas em 141 municípios.
} 
e $20,08 \%$, respectivamente, indicaram a qualificação dos professores. ${ }^{10}$ Apesar de diferentes abordagens e alternativas elencadas nestes estudos, essas duas temáticas fundamentais se destacaram nos dois levantamentos. Cabe aqui apresentar um dado do Anuário Brasileiro da Educação (2014, p.12), que pode explicar a preocupação de grande parte da população pesquisada em relação aos salários dos educadores, pois o professor da Educação Básica recebe em média $\mathrm{R} \$$ 1.874,50, sendo que esse valor é a metade do salário médio dos profissionais de nível superior completo e cerca de três vezes menor do que a média dos vencimentos dos profissionais da área de exatas.

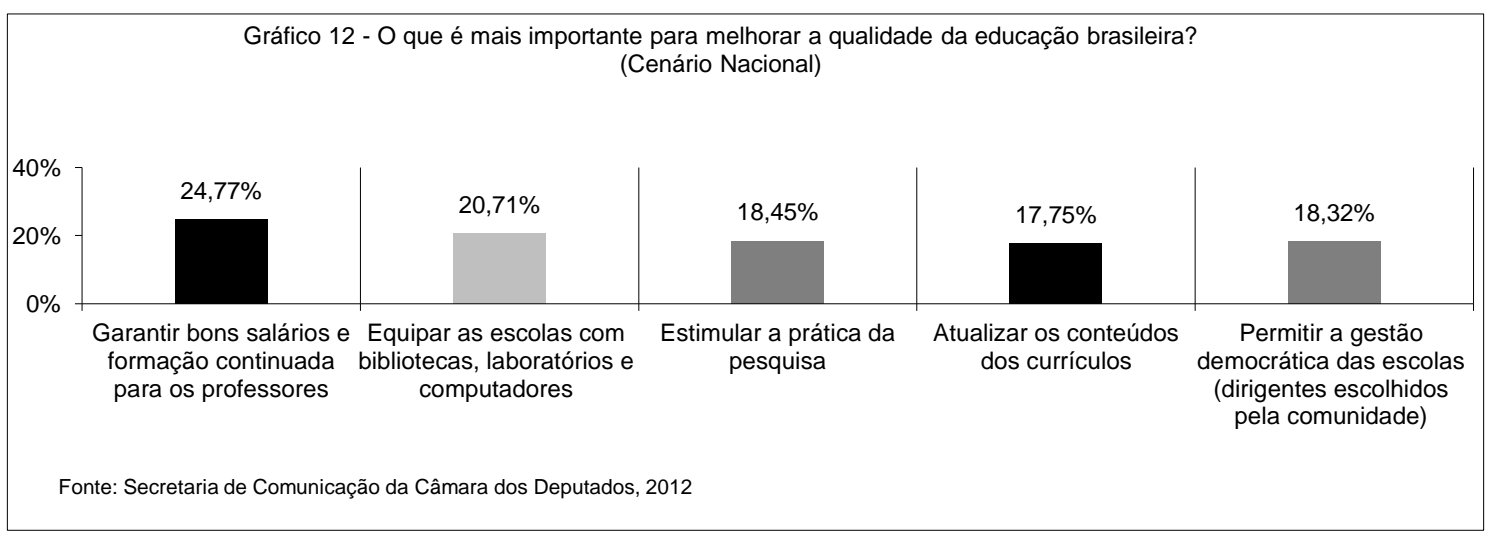

Assim como no cenário geral, nesse tópico, quanto à escolaridade, também predominam as respostas que atribuem maior relevância aos salários, à formação continuada dos professores e à infraestrutura das escolas (bibliotecas, laboratórios e computadores), como mostra o Gráfico 13.

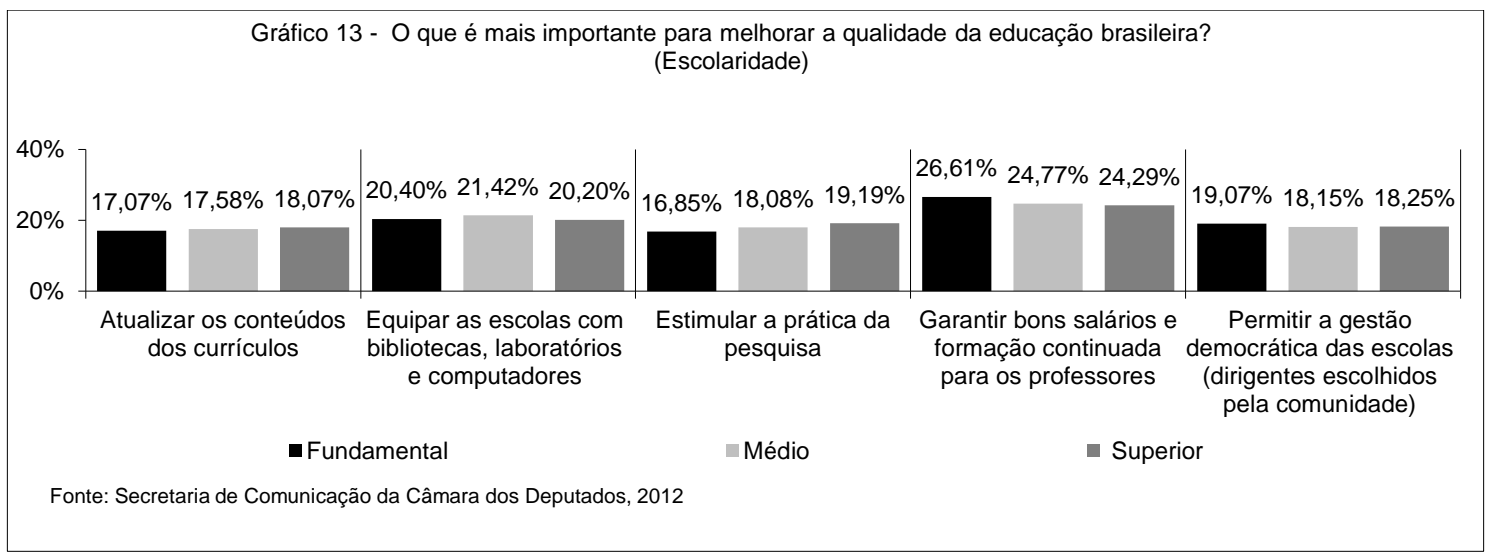

\subsection{Percepção dos cidadãos sobre avanços na educação}

Indagados se reconhecem algum avanço na educação pública nos últimos anos, 42,08\%

\footnotetext{
${ }^{10}$ As alternativas apresentadas em 2011 foram estas: baixos salários, professores sem qualificação, estrutura física ruim, dificuldade de chegar à escola, falta de vagas, falta de merenda e material didático ruim. Em 2013, foi acrescentada a alternativa 'greves frequentes' que recebeu 9,9\% das respostas como o principal problema da educação pública.
} 
dos cidadãos optaram pelo "sim" e 20,30\% responderam "em parte" (Gráfico 14). Somados os dois itens dos que reconhecem avanços (total e parcial), chega-se ao total de 63,38\%, o que representa elevada percepção social sobre melhorias no ensino público brasileiro nas últimas décadas, especialmente após o início da vigência da LDB, em 1996.

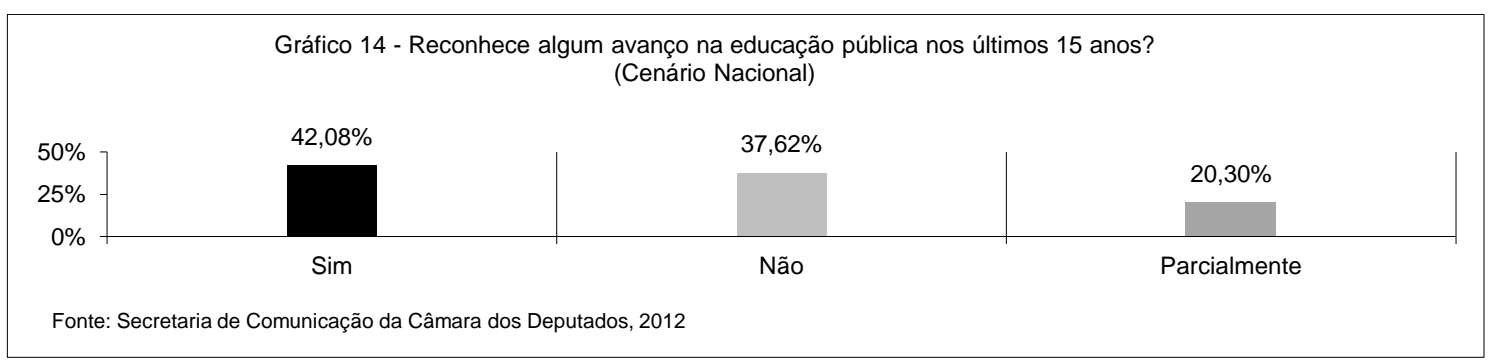

A opinião muda quando se trata do tópico que avalia se os cidadãos reconhecem avanços no campo educacional durante o período dos 15 anos de vigência da LDB. Como mostra o Gráfico 14, quanto maior a escolaridade, maior o percentual de respostas afirmativas (considerando-se o somatório do "sim" e do "parcialmente", visto que este último também é uma resposta afirmativa). Contudo, o Gráfico 15 reforça a consonância com o cenário geral, reiterando a ideia de que nem sempre a variável escolaridade é relevante para definir a percepção dos respondentes sobre as problemáticas educacionais. Conclusão semelhante foi observada pelo estudo de Barros e Martins (2014) acerca das percepções sociais sobre os efeitos da Lei de Diretrizes e Bases da Educação (LDB) e das expectativas em torno no Plano Nacional de Educação (PNE). Isso não significa que a instrução seja irrelevante ou desprezível, mas que não constitui fator predominante para definir o modo de avaliar questões e problemáticas variadas sobre educação. Em alguns casos específicos, o tempo de escolarização influencia a opinião do cidadão, mas essa premissa não pode ser generalizada para todos os casos.

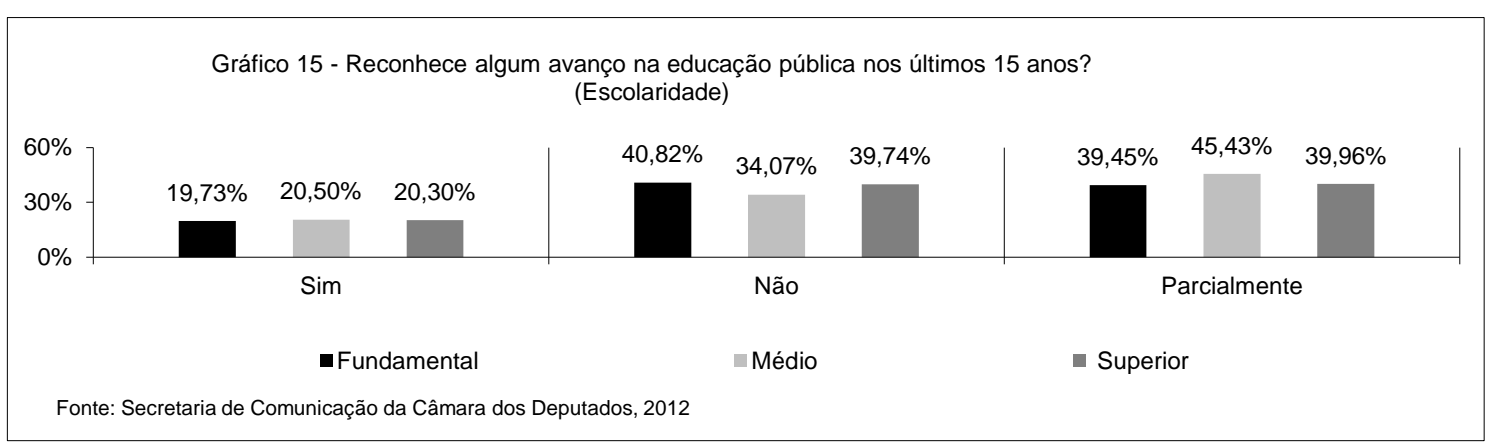

Entre os avanços mais destacados pela população consultada estão os seguintes: (a) ampliação das redes de escolas técnicas e tecnológicas (14,48\%); (b) criação dos sistemas de avaliação do ensino como o PAS e o $\operatorname{ENEM~}(14,40 \%)$; e a implantação de universidades no interior do País (13,87\%). O detalhamento estatístico consta nos Gráficos 16 e 17. 
Gráfico 16 - Que avanços da educação considera mais importante nos últimos 15 anos?

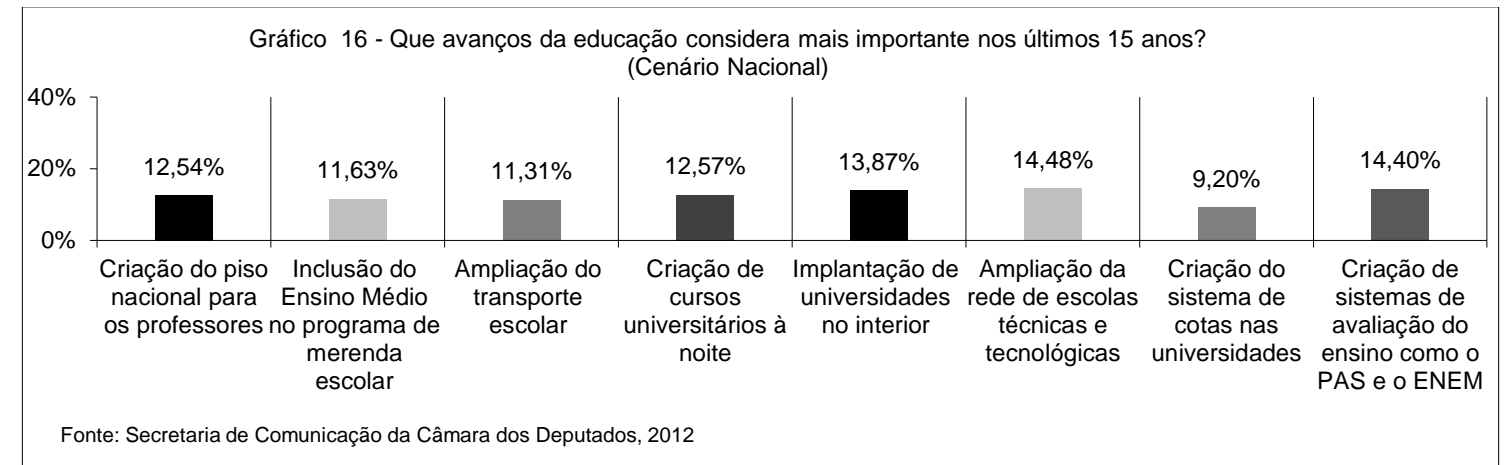

Chama atenção a dispersão das respostas quanto ao reconhecimento dos avanços da educação nos últimos anos, conforme mostram os dados expostos nos gráficos 16 e 17. Destaca-se a proximidade dos percentuais entre todos os itens pesquisados, com uma escala de pequenas variações. Os menores percentuais registrados se referem à criação do sistema de cotas nas universidades públicas, com 9,2\% no cenário nacional. Ao se considerar a variável escolaridade, o Gráfico 17 mostra os seguintes percentuais: 10,26\% para os informantes com o ensino fundamental; 9,36\% para os do ensino médio; e 8,8\% para os portadores de diploma de curso superior. A pulverização das respostas pode constituir um indicador de que há um reconhecimento social de avanços nas variadas áreas educacionais, fruto de uma ampla pauta de políticas públicas protagonizadas pelo poder público brasileiro, incluindo o Legislativo, conforme mostra o estudo de Martins (2011). Portanto, a população não acompanha os debates diretamente por meio dos agentes políticos, mas toma conhecimento pelos variados meios de informação, confirmando a tese da crescente midiatização da política e em especial do parlamento (MANIN, 2013; URBINATI, 2013).

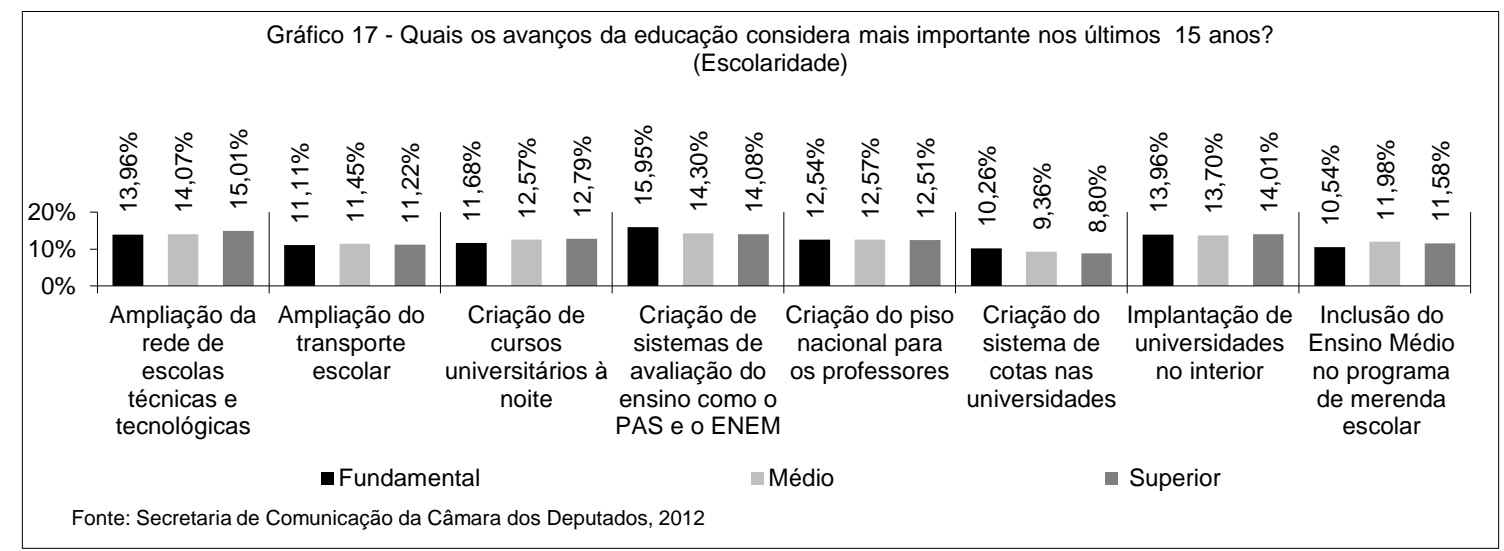

Em contraponto a essa percepção de avanços na educação pública por grande parte do público pesquisado, mais da metade da população avalia esse serviço público como ruim ou péssimo, sendo que essa insatisfação demonstra-se crescente nas pesquisas de opinião do Senado 
Federal. Em 2011 e 2013, 37\% e 53,8\%, respectivamente, afirmaram ser ruim ou péssima; 44\% e $36 \%$ afirmaram ser regular. Consideravam ser ótima ou boa apenas $18 \%$ e $9 \%$, respectivamente (BRASIL, 2011 e 2013).

\section{Conclusão}

No que se refere aos dados gerais cabe destacar as tendências de opinião dominantes, especialmente no tocante à atenção prioritária do Poder Legislativo em relação aos diferentes níveis da educação básica (educação infantil, ensino fundamental e ensino médio), além do ensino técnico e profissionalizante. Isso revela que a preocupação maior dos cidadãos consultados ainda é com o nível elementar e instrumental do ensino público. Essa posição é corroborada pelos dados da pesquisa do Senado Federal, na qual o ensino fundamental é apontado como prioridade para a destinação de recursos públicos na educação. Essa necessidade pode ser reforçada pela demanda não atendida na educação infantil ( 0 a 5 anos), o que representa um grande desafio ao Governo Federal, principalmente após a aprovação do PNE, que ataca diretamente esse problema em suas metas. Ainda no contexto do financiamento da educação, o salário dos professores é apontado pelas três pesquisas de opinião aqui abordadas e pelo Anuário Brasileiro da Educação Pública de 2014 como o principal problema da educação pública no Brasil. Essa situação não foi resolvida pela criação do piso nacional da educação básica (Lei $\mathrm{n}^{\circ}$ 11.738/2008), que definiu o piso salarial em $\mathrm{R} \$ 950,00$ e, em 2014, elevou o valor para $\mathrm{R} \$ 1.697,00$, referente a 40 horas semanais.

Em relação ao papel da educação, as respostas indicam certo grau de complexidade e de ambiguidade, o que dificulta uma conclusão fechada. Em alguns casos, a depender de como a pergunta é formulada, os cidadãos privilegiam os aspectos de formação intelectual, cultural, moral e ética do ensino público, além do fomento ao respeito à diferença, à diversidade e aos direitos humanos. Em outros casos reafirmam a função da escola na formação profissional, por exemplo. Talvez essa tendência seja um indicativo de que a população entende a educação tanto em sua dimensão instrumental e utilitária (alfabetização, formação técnica e profissional) como em sua dimensão de formação humana e cidadã. As duas visões seriam indissociáveis e complementares, portanto.

No âmbito da variável grau de instrução, observa-se que, de fato, o grau de escolaridade é um fator interveniente na percepção dos cidadãos sobre os principais aspectos da educação contemplados pela sondagem. Entre os fatores que se destacam, chamam a atenção especialmente as concepções dos respondentes com nível superior, sobretudo no que se refere à importância da pesquisa científica, à atualização dos conteúdos dos currículos escolares e à melhoria das bibliotecas, por exemplo.

A partir dessas ponderações conclui-se, no entanto, que a educação ainda não é reconhecida pela população consultada (apesar desse perfil específico) como um tema político, 
no sentido amplo do termo. Apesar de ser apontada consensualmente como uma questão de interesse nacional (como algo importante para todo o País e não apenas para uma ou outra região), é vista mais como um problema social e cultural, sem ênfase para a conotação política.

Outro dado que merece destaque é aquele relativo ao papel do Poder Legislativo no âmbito da educação. Promover debates sobre os temas educacionais, por exemplo, uma das opções de resposta do questionário na parte específica sobre este assunto (Gráfico 6), foi uma das menos citadas pelos respondentes. No cenário nacional o quantitativo de respostas foi de 20,02\%, percentual similar no cenário relacionado com a escolaridade. Entretanto, o Gráfico 7 mostra que os respondentes com nível superior priorizam as alternativas "Fiscalizar a aplicação dos recursos públicos em educação" (31,44\%) e "Aprovar medidas que promovam a capacitação dos professores e servidores da educação" (25,78\%).

Em suma, a educação é reconhecida em todos os cenários de opinião como um tema relevante em âmbito nacional do ponto vista social e cultural, mas sua conotação política é pouco destacada, principalmente quando se trata do reconhecimento da esfera do Poder Legislativo como uma instância de debate sobre políticas públicas educacionais. Aliás, o papel do Poder legislativo é associado pelos cidadãos consultados diretamente à garantia de recursos orçamentários e à fiscalização financeira relativa à aplicação dos investimentos públicos no setor.

Do ponto de vista da relação dos dados com o referencial teórico utilizado no texto, as inferências apontam para uma falta de confluência entre as percepções da sociedade e a noção de educação como processo de racionalização cultural e social. Em termos mais amplos, os dados mostram ainda baixa correlação da perspectiva da opinião pública com os pressupostos teóricos ancorados nas premissas do modelo republicano de democracia, no qual a formação da opinião e da vontade coletiva é um dos aspectos fundamentais da esfera pública moderna. A educação é reconhecida pelos cidadãos consultados como relevante para o fortalecimento da esfera pública, mas desvinculada da concepção republicana de democracia e sua perspectiva de ênfase nos aspectos deliberativos habermasianos.

Da mesma forma, na visão dos cidadãos consultados, o Poder Legislativo, no que se refere às políticas públicas para o setor educacional, é percebido mais como órgão responsável pela alocação de recursos para financiar o ensino público (Gráfico 7). A perspectiva deliberativa da democracia, com ênfase para o debate racional e a troca pública de razões é pouco valorizada pela opinião pública no que se refere à atuação do parlamento e ao campo das políticas públicas educacionais. "Nesse sentido, reforça-se a ideia do Estado como provedor e garantidor de serviços e dos indivíduos como cidadãos-clientes" (BARROS e MARTINS, 2014, p.103). Entretanto, tais aspectos necessitariam de aprofundamento maior, o que poderia ser objeto de outro artigo, com abordagem teórica ancorada na atuação legislativa e seus reflexos na opinião pública, em termos de longo prazo. 
É oportuno comentar ainda a sistematização dos dados em dois cenários de opinião, sendo um com a totalização das respostas (cenário nacional) e o outro com as percepções agregadas conforme o nível de escolaridade. O que se observa é que, de fato, o grau de escolaridade é um fator interveniente na percepção dos cidadãos sobre os principais aspectos da educação contemplados pela sondagem. Chamam a atenção especialmente as concepções dos respondentes com nível superior, sobretudo no que se refere a aspectos relacionados à formação de uma cultura científica e à organização curricular, em sintonia com as conclusões de estudo anterior realizado sobre as percepções sociais acerca da LDB e do PNE (BARROS e MARTINS, 2014, p.103): “A distinção do ponto de vista do nível de escolarização corrobora os pressupostos gerais do referencial sociológico utilizado no estudo, especialmente no que se refere ao princípio weberiano da racionalização. Quanto maior o grau de instrução do cidadão consultado na pesquisa, maior sua capacidade de formular argumentos racionais e de opinar sobre as questões postas pela sondagem de opinião". Entretanto, como já foi ressaltado anteriormente, não é possível generalizar que o nível de escolaridade constitui variável determinante para definir a opinião cidadã em todos os aspectos.

\section{Referências}

ARENDT, H. A condição humana. Rio de Janeiro: Forense, 1983.

Eichmann em Jerusalém: um relato sobre a banalidade do mal. São Paulo: Companhia das Letras, 1999.

Entre o passado e o futuro. São Paulo: Perspectiva, 2000.

. O que é política. Rio de Janeiro: Bertrand Brasil, 2004.

. Entre o passado e o futuro. São Paulo: Perspectiva, 2000.

BARROS, A. T.; MARTINS, L. M. Legislação, Educação e Política: percepções sociais sobre a Lei de Diretrizes e Bases e o Plano Nacional de Educação (2011-2020). Política \& Sociedade, Florianópolis, 2014. v. 13, n. 27, p. 77-109.

BRASIL. Senado Federal. Pesquisa Educação Pública no Brasil - Pesquisa de opinião pública nacional. Secretaria Especial de Comunicação Social, Secretaria de Pesquisa de Opinião Pública, Data Senado, Brasília, 2011. Disponível em:

http://www.senado.gov.br/comissoes/ce/documentos/pesquisaeducacaopublicabrasil.pdf Consultado em 17/11/14. Acesso em: nov. 2014.

BRASIL. Senado Federal. Pesquisa Federalização da Educação. Secretaria de Transparência, Coordenação de Pesquisa e Opinião, Data Senado, Brasília, 2013. Disponível em: http://www.senado.gov.br/senado/datasenado/pdf/datasenado/DataSenado_Relatorio_da_pesqui sa sobre federalizacao de educacao v3.pdf Acesso em: nov. 2014.

BOURDIEU, P; PASSERON, J. C. A reprodução. Elementos para uma teoria do sistema de ensino. Rio de Janeiro: Francisco Alves, 1975. 
COSSON, Rildo. Escolas do Legislativo, escolas de democracia. Brasília: Edições Câmara, 2008.

CRUZ, Priscilla; MONTEIRO, Luciano (org). Anuário Brasileiro da Educação Básica 2014. Movimento Todos pela Educação e Editora Moderna, São Paulo, 2014. Disponível em: http://www.todospelaeducacao.org.br/biblioteca/1493/anuario-brasileiro-da-educacao-basica2014/ Acesso em 17 nov. 2014.

DOMINGUES, José Maurício. A cidade: racionalização e liberdade em Max Weber. In: SOUSA, Jessé (org). A atualidade de Max Weber. Brasília: Editora da Universidade de Brasília, 2000. p. 209-234.

HABERMAS, J. Teoría de la acción comunicativa, Madrid: Taurus, 1987. v. I.

Direito e democracia. Rio de Janeiro: Tempo Brasileiro, 1997.

IBOPE. PESQUISA DE OPINIÃO PÚBLICA SOBRE A EDUCAÇÃO BÁSICA PÚBLICA NO BRASIL. Ibope Inteligência, dezembro de 2008. Disponível em: http://g1.globo.com/jornaldaglobo/download/0,4714-1,00.pdf Acesso em: nov. 2014.

MANIN, Bernard. A democracia do público reconsiderada. Novos Estudos CEBRAP. São Paulo, 2013. p. 115-127, n. 97.

MARQUES JÚNIOR, Alaôr Messias. Educação legislativa: as escolas do Legislativo e a função educativa do parlamento. E-Legis, 2009, v. 2, n. 3, p.73-86. Disponível em:

http://bd.camara.gov.br/bd/handle/bdcamara/2263. Acesso em 22 fev. 12.

MARTINS, Ricardo Chaves de Rezende. O Poder Legislativo e as políticas públicas educacionais no período de 1995-2010. Tese de doutorado. Universidade Estadual do Rio de Janeiro. Programa de Pós-Graduação em Sociologia e Ciência Política, 2011. 223f.

PAUL, J.; BARBOSA, M. L. O. Qualidade docente e eficácia escolar. Tempo Social, São Paulo, 2008. p. 119-133, v. 20, n. 1.

RIBEIRO, Guilherme Wagner. A educação legislativa é uma resposta à crise do parlamento? ELegis, 2011, v. 4, n. 6, p. 96-103. Disponível em http://elegisbr.com/cefor/index.php/elegis/article/view/68/69. Acesso em 22.02.12.

SOUSA, Jessé. Acerca do lugar da moralidade na política: Weber, Habermas e a singularidade cultural alemã. In: SOUSA, Jessé. (org). A atualidade de Max Weber. Brasília: Editora da Universidade de Brasília, 2000. p. 49-90.

URBINATI, N. Crise e metamorfoses da democracia. Revista Brasileira de Ciências Sociais, São Paulo, 2013. p. 5-16, v. 28, n. 82.

WEBER, M. O Parlamento como órgão do Estado e o problema da publicidade da administração. A tarefa da seleção de líderes. Economia e Sociedade. Brasília: Editora da UnB, 1999. p. 560-580.

Artigo recebido em: 01/09/2014

Artigo aceito para publicação em: 24/11/2014 